\title{
Rotationally stocked beef cattle responses to daily and weekly residence
}

\author{
N. S. BOYD, T. ASTATKIE, A. H. FREDEEN, AND R. C. MARTIN
}

The authors are an agronomy graduate student in the Department of Plant Science, a statistician and Associate Professor in the Department of Mathematics, Physics and Humanities, a ruminant nutritionist and Professor in the Department of Animal Science and an agronomist and associate professor in the Department of Plant Science at the Nova Scotia Agricultural College, Truro, N.S., Canada B2N 5 E3.

\begin{abstract}
Rotational stocking is a component of intensive pasture management and involves the systematic movement of animals among paddocks to optimize harvest of digestible nutrients. The optimum period of residence time for beef cattle in a paddock has not been researched in Atlantic Canada. A series of experiments were conducted at the Nova Scotia Agricultural College during the 1994, 1995, and 1996 grazing seasons to determine if short residence times ( 1 day) or longer residence times (6 or 7 days) encouraged higher average daily gains (ADG) in beef cattle. In 1994 and 1995, Hereford steers were used, and in 1996, Hereford heifers were used to compare the effects of daily and weekly residence times. In the mid to late season of 1994, a preliminary study with fewer replicates than in 1995 and 1996 indicated that the steers with a daily and weekly residence time gained 1.18 and $1.09 \mathrm{~kg}_{\text {animal }}{ }^{-1}$ day $^{-1}$, respectively. Based on these results the project was expanded with the hypothesis that daily residence times result in higher average daily gains compared with weekly residence times. In both 1995 and 1996, cattle ADG for the first part of the season was higher with weekly residence times and similar near mid-season. Near the end of the grazing season the trend reversed with the daily residence time producing a higher cattle ADG. The results of this study indicate that animal performance could be maximized by long rotation cycles during periods of rapid forage growth and short rotation cycles during periods of slow forage growth. In all years, animals were finished on pasture with no visible yellow fat.
\end{abstract}

Key Words: average daily gain, period of stay, repeated measures, rotational grazing, white clover, yellow fat

Rotational stocking involves strategical and sequential movement of livestock through paddocks to optimize use of the available forage. Some claim an increase in stocking rate without compromising weight gains of individual animals. Bertelson et al. (1993) reported a $42 \%$ increase in stocking rate without decreasing animal gains on alfalfa (Medicago sativa L.), fescue (Festuca arundinacea Schreb.), and orchard grass (Dactylis glomerata L.) pastures. Increased individual animal gains with increased stocking rate may be due to increased forage production or quality. While

Research was funded in part by Nova Scotia Department of Agriculture and Marketing Research Grants. The authors thank Ignatius Augustin and Gary Wallace for technical assistance and practical advice.

Manuscript accepted 24 Apr. 2000

\section{Resumen}

El apacentamiento rotacional es un componente del manejo intensivo de praderas que implica el movimiento sistemático de los animales entre los potreros para optimizar la cosecha de nutrientes digestibles. El periodo óptimo de residencia del ganado en el potrero no ha sido estudiado en la región atlántica de Canadá. Durante la estación de apacentamiento de los años 1994, 1995 y 1995 se condujo una serie de experimentos en la Universidad Agrícola de Nueva Escocia con el objetivo de determinar si tiempos cortos de residencia (1 día) o tiempos largos (6 o 7 días) fomentan mayores ganancias diarias de peso (GDP) en ganado de carne. En 1994 y 1995 se utilizaron novillos Herford y en 1996 se utilizaron vaquillas de esta misma raza, estos animales se utilizaron para comparar los efectos de los tiempos de residencia diaria y semanal. Un estudio preliminar con menos repeticiones que los estudios de 1995 y 1996 y conducido de mediados a fines de la estación de 1994 indicó que los novillos con tiempos de residencia diaria y semanal ganaron 1.18 y 1.09 $\mathrm{kg}_{\text {animal }}{ }^{-1}$ día $^{-1}$ respectivamente. Basados en estos resultados el proyecto se extendió con la hipótesis de que tiempos de residencia de un día resultan en mayores ganancias diarias de peso que los tiempos de residencia de una semana. En 1995 y 1996 la GDP durante la primer parte de la estación de apacentamiento fue mayor con los tiempos de residencia semanales e igual a mediados de la estación. Cerca del final de la estación de apacentamiento la tendencia se revertió y los tiempos de residencia diarios produjeron las mayores GDP del ganado. Los resultados de este estudio indican que el comportamiento productivo del animal pudiera ser maximizado mediante ciclos de rotación largos durante la etapa de crecimiento rápido del forraje y ciclos de rotación cortos durante los periodos de crecimiento lento del forraje. En todos los años los animales fueron finalizados en la pradera sin la acumulación visible de grasa amarilla.

some authors have reported no increase in forage quality with rotational grazing (Walker et al. 1989, Popp et al. 1997), Heitschmidt et al. (1987) reported that rotational stocking raised crude protein content and reduced litter in the sward. They attributed the difference to less mature plants, as a result of grazing pressure.

Little work has been done to determine the optimum period of time for beef cattle to remain in a given paddock. Some research suggests the longer the animals remain in a paddock the lower the forage quality with some plant species (Morrow et al. 1991). Bertelsen et al. (1993) found no significant difference in sward quality with a 3 or 6 day residence time in a mixed pasture. 
However, the paddocks where the animals remained for 3 days tended to have more available forage before grazing than the paddocks where the animals remained for 6 days.

The purpose of this research was to examine the effects of daily and weekly residence times on beef cattle average daily gains (ADG) while holding forage availability as constant as possible by adjusting paddock size according to forage height. Secondary objectives were to determine the presence or absence of yellow fat on the carcasses of cattle, the seasonal forage yield, and the white clover proportion of forage.

\section{Materials and Methods}

\section{Study site}

The study was conducted from 1994 to 1996 at the Nova Scotia Agricultural College in Truro, Nova Scotia, Canada $\left(45^{\circ}, 14^{\prime} \mathrm{N}, 63^{\circ}, 19^{\prime} \mathrm{W}\right)$. The pasture was composed mostly of Kentucky bluegrass (Poa pratensis L.), meadow fescue (Festuca pratensis Huds.), meadow foxtail (Alopecurus pratensis L.), and common white clover (Trifolium repens L.) grown on a Woodville Sandy loam soil (orthic humo-ferric podzol).

\section{Field design}

The experiment was designed to examine the effect of daily versus weekly residence time (every 6 days in 1994 and 1995 and every 7 days in 1996) in a paddock on average daily gain (ADG) and weight of cattle. In 1994, preliminary research was conducted with 6 cattle per treatment and 2 replications of each treatment. In 1995 and 1996, each treatment was replicated 4 times with 4 animals allocated to each treatment, within each replicate.

A 6.4 ha field was divided into 4 strips, $50 \mathrm{~m}$ by $320 \mathrm{~m}$, using a high tensile power fence. Within each strip or replicate, each treatment was randomly allocated to one end or the other. The paddocks were formed within the strips with strands of polywire, perpendicular to the high tensile wires forming the experimental unit. Mineral supplement and water was provided within each paddock.

\section{Paddock Rotation}

The experiment began on 19 July in 1994, 24 May in 1995, and 28 May in 1996. At the beginning of each season, animals moved daily had a paddock $6 \mathrm{~m}$ by $50 \mathrm{~m}$, and the animals moved weekly had a paddock $40 \mathrm{~m}$ by $50 \mathrm{~m}$. Before moving cattle to a new paddock, its size was determined according to forage regrowth since the previous grazing cycle, as indicated by forage height. Paddock size was increased if the residual forage was less than $5 \mathrm{~cm}$ tall or if the forage in the new paddock was less than $20 \mathrm{~cm}$. The paddock size was reduced if the residual forage exceeded $7 \mathrm{~cm}$ or the available forage was more than $25 \mathrm{~cm}$ in the new paddock. Every 6 meters, sward heights were measured with a meter stick. Six heights were taken from the daily residence time paddocks and 30 heights taken from the weekly residence time paddocks. All dung patches or excessively tall grass due to urination were avoided to prevent measuring forage that animals typically will not consume.

The 2 treatments were randomly allocated to each end of a strip and the cattle moved through progressive paddocks toward the centre of the strip. Forage heights in the first paddock were monitored consistently while the animals continued to move towards the centre. When the forage in the first paddock was between 20 and 25 $\mathrm{cm}$ the animals returned to that paddock initiating a new rotation.

\section{Animal Weights}

In 1994, 24 Hereford crossbred steers were weighed on 19 July and 6 October. In 1995, 32 male crossbred Hereford steers were weighed on the 23 and 24 of May and averaged to obtain their initial weight before the start of the pasture project. Animals were weighed 2 weeks prior to the initial weighing in the field while in the barn to determine the effects of the transition from silage to pasture. The herd was sorted into groups of 4 with all groups having similar total group weights. The animals were weighed once monthly during the summer and on 2 consecutive days before slaughter. The same procedure was used in 1996, except that Hereford crossbred heifers were used instead of steers. The grazing season ended when forage regrowth had slowed to the point that forage heights were too low for cattle to graze.

All animals were slaughtered directly off pasture to determine whether they would be down-graded for yellow fat. Many Maritime farmers will feed grain to cattle before slaughter regardless of age, genetics, fatness, or animal gender.

\section{Forage Production}

Forage mass was estimated by clipping $0.2 \times 0.5 \mathrm{~m}$ quadrats to ground level. Forage from a $0.15 \mathrm{~m} \times 0.15 \mathrm{~m}$ area within the quadrat was sorted into grass and white clover to determine composition. Six samples were taken from the daily residence time paddock and 12 from the weekly residence time paddock. All samples were oven dried at $80^{\circ} \mathrm{C}$ for at least 48 hours to determine forage mass dry matter at time of entrance. In 1995, forage samples were taken from every seventh paddock from the daily residence time treatment. In the weekly residence time paddocks, samples were taken in every second paddock and a total of 8 samples were taken with the small and large quadrats. Samples from the daily and weekly residence time treatments were not taken on the same day, therefore, they could not be compared statistically but general seasonal patterns could be observed. In 1996, forage samples were taken every 2 weeks from daily and weekly residence time treatments just before cattle entered the assigned paddocks.

\section{Statistical methods}

Weight response of cattle was measured on 5 occasions between May and September in both years. Forage dry matter was measured on 7 occasions between May and August in 1995 and on 6 occasions in 1996. Treatment effects over the growing season were estimated as repeated measures, using the GLM procedure of SAS (SAS institute Inc., 1990). For comparing the actual weight responses from daily and weekly residence times, measured at the various weighing times, the initial weights (in the barn just before the animals were taken to pasture) were used as covariates. For the average daily gain (ADG) response, to account for the differences in the initial weight of the animals, the analysis was done on weight changes between 5 July and 24 May, 2 August and 5 July, etc. This procedure amounts to using initial weight as a covariate for each measurement time. In all the analyses, the residuals were examined as described by Montgomery (1997) to verify the normal distribution and constant variance assumptions needed for the validity of the statistical tests.

\section{Results}

\section{Animal Weights}

In 1994 between late July and late September, the average daily gain (ADG) was 1.18 and $1.09 \mathrm{~kg}$ gain day ${ }^{-1}$ for daily and weekly residence times, respectively $(\mathrm{p}<0.05)$. Given this result, the project was expanded and continued in 1995 and 1996 to examine whether animals moved 
Table 1. Least squares means (LSM) of actual weights (kg) along with P-values for testing the equality of the weights from daily residence times (DRT) and weekly residence times (WRT). These values were obtained by using their initial (barn) weight as a covariate.

\begin{tabular}{lcccc}
\hline \hline Year & Date & LSM-DRT & LSM-WRT & P-value \\
\hline 1995 & 24 May & 290 & 294 & $0.341^{1}$ \\
& 5 July & 349 & 368 & 0.001 \\
& 2 Aug. & 370 & 398 & 0.002 \\
& 29 Aug. & 393 & 423 & 0.001 \\
& 20 Sept. & 414 & 433 & 0.005 \\
1996 & 28 May & 289 & 289 & 0.972 \\
& 25 June & 334 & 342 & 0.003 \\
& 23 July & 352 & 364 & 0.019 \\
& 8 Aug. & 364 & 379 & 0.009 \\
& 11 Sept. & 386 & 384 & 0.866 \\
\hline
\end{tabular}

${ }^{\mathrm{P}}$-values less than 0.05 suggest significant difference at the $5 \%$ level.

daily continued to obtain greater gains than the animals moved on a weekly basis.

In 1995 and 1996, the initial weights of the cattle in both treatments were similar (Table 1). In 1995, the animal weights of the cattle with a weekly residence time were significantly higher at each subsequent weighing. These responses were repeated in 1996 except for the final weights that were not significantly different.

In 1995, the animals lost weight during the transition period from feedlot to pasture. The animals moved weekly lost 0.47 $\mathrm{kg}$ day $^{-1}$ compared with a loss of $0.67 \mathrm{~kg}$ day $^{-1}$ for the daily residence time ( $\mathrm{p}=$ 0.11 ) (Table 2). Weight gains were significantly higher for the weekly residence time at 2 of the subsequent three weighings. Thereafter the trend reversed with the daily residence time treatment gaining significantly more between August 29 and September $20(\mathrm{p}=0.003)$.

From 24 May to 5 July there was a significant weight gain $(\mathrm{p}=0.0001)$ for both treatments with the difference between the magnitude of ADG due to the 2 treatments remaining constant between the 2 time points $(\mathrm{p}=0.123)$ (Table 2$)$. The ADG for both treatments declined $(\mathrm{p}=0.0001)$ between 5 July and 2 August. Between 2 August and 29 August, however, ADG was similar $(\mathrm{p}=0.189)$ and the treatment effect between time points did not differ ( $\mathrm{p}$ $=0.418$ ). Between 29 August and 20 September, ADG for the weekly residence time declined $(p=0.005)$. The ADG for the daily residence time increased slightly, which resulted in a significantly higher ADG for the daily residence time than the weekly residence time $(p=0.003)$. Over the grazing season, the ADG for the weekly residence time was significantly higher $(\mathrm{p}=0.009)$.

Similar trends were noted in 1996 (Table 3). The ADG dropped between 25 June and 23 July $(\mathrm{p}=0.000)$ for both treatments giving a non-significant treatment $\mathrm{x}$ time interaction effect $(\mathrm{p}=0.526)$. Between 23 July and 8 August, ADG did not increase significantly for either treatment $(\mathrm{p}=0.093)$ and the treatment $\mathrm{x}$ time interaction effect remained constant $(\mathrm{p}=$ 0.991). Between 8 August and 11 September rate of gain of heifers with a daily residence time was over 2.5 times greater than heifers on weekly residence time $(\mathrm{p}=0.002)$. The ADG for both treatments fell significantly $(p=0.006)$, more abruptly for weekly than for daily residence time $(p=0.03)$. Unlike the result in 1995, over the grazing season, the ADG of both treatments were equal $(p=0.428)$.
Without exception, in both years, the carcasses of cattle (64 steers and heifers) from this experiment were not down-graded for the presence of yellow fat (data not shown).

\section{Pasture Production}

The available biomass varied between treatment and year. During the first year of the project there was a seasonal average of 3,292 and $3,435 \mathrm{~kg} \mathrm{ha}^{-1}$ of dry matter mass before each grazing event in daily and weekly residence time paddocks, respectively. The available dry matter was extremely high because the animals did not begin grazing until late in the season. The seasonal average of available biomass dropped, in 1995 , to 1,466 in the daily residence time paddocks and $1,292 \mathrm{~kg} \mathrm{ha}^{-1}$ in the weekly residence time paddocks (Table 4). The exceptional increase of forage biomass from 24 May to 29 May can be attributed to the movement of cattle from areas of low biomass to those with higher biomass and to improving seasonal growth. In 1996, there were 1,394 and 1,544 $\mathrm{kg} \mathrm{ha}^{-1}$ of dry matter available in daily and weekly residence time paddocks, respectively. Due to an oversight, in 1995 the available dry matter and percent clover in a paddock before grazing were not measured at the same time and hence could not be compared statistically. However, daily residence time paddocks tended to have more forage available within the paddocks than weekly residence time paddocks.

The white clover content of the pasture also declined over the 3 year period (Table 4). In 1994, there was approximately 56.7 and $52.3 \%$ clover in daily and weekly residence time paddocks, respectively. The clover content declined in 1995 to a seasonal average of $16.3 \%$ in daily residence paddocks and $13.3 \%$ in weekly residence paddocks. The decline continued in 1996 with a seasonal average of $12.3 \%$ for both treatments. The percent clover was not dif-

Table 2. Summary of the 1995 repeated measures analysis results on average daily gains (ADG) of cattle with a daily residence time (DRT) and a weekly residence time (WRT). A p-value (shown in italics) of less than the level of significance (say, $5 \%$ ) suggests significant difference.

\begin{tabular}{|c|c|c|c|c|c|c|}
\hline Source & $\begin{array}{c}24 \text { May-barn } \\
\text { (1) }\end{array}$ & $\begin{array}{c}5 \text { July-24 May } \\
\text { (2) }\end{array}$ & $\begin{array}{c}2 \text { Aug. }-5 \text { July } \\
\text { (3) }\end{array}$ & $\begin{array}{c}29 \text { Aug.-2 Aug. } \\
\text { (4) }\end{array}$ & $\begin{array}{c}20 \text { Sept.-29 Aug. } \\
\text { (5) }\end{array}$ & Over the season \\
\hline Treatment & $0.113^{2}$ & 0.0001 & 0.291 & 0.004 & 0.003 & 0.009 \\
\hline ADG-DRT & -0.67 & 2.12 & 0.79 & 0.83 & 0.90 & 0.79 \\
\hline ADG-WRT & -0.47 & 2.64 & 0.95 & 1.11 & 0.45 & 0.94 \\
\hline \multicolumn{2}{|c|}{ Difference between time points } & $(2)-(1)$ & (3) $-(2)$ & (4) $-(3)$ & (5) $-(4)$ & \\
\hline \multirow{2}{*}{\multicolumn{2}{|c|}{$\begin{array}{l}\text { Mean } \\
\text { Treatment }\end{array}$}} & $0.0001^{3}$ & 0.0001 & 0.189 & 0.005 & \\
\hline & & $0.123^{4}$ & 0.123 & 0.418 & 0.0001 & \\
\hline
\end{tabular}

${ }_{2}$ Cattle were weighed in barn in 1995 prior to being put on pasture

${ }_{3}^{2} \mathrm{p}$-value to compare DRT and WRT within a weighing time

3 -value to compare the effect of consecutive weighing times on ADG across time

4 -value to compare the magnitude of the difference between DRT and WRT at consecutive weighing times, i.e. the treatment $\mathrm{x}$ time interaction 
Table 3. Summary of the 1996 repeated measures analysis results on average daily gains (ADG) of cattle with a daily residence time (DRT) and a weekly residence time (WRT). A p-value (shown in italics) of less than the level of significance (say, $5 \%$ ) suggests significant difference.

\begin{tabular}{|c|c|c|c|c|c|}
\hline Source & $\begin{array}{c}25 \text { June-28 May } \\
\text { (1) }\end{array}$ & $\begin{array}{c}23 \text { July. }-25 \text { June } \\
\text { (2) }\end{array}$ & $\begin{array}{c}8 \text { Aug.-23 July } \\
\text { (3) }\end{array}$ & $\begin{array}{c}11 \text { Sept. }-8 \text { Aug.20 } \\
\text { (4) }\end{array}$ & Over the season \\
\hline Treatment & $0.052^{T}$ & 0.320 & 0.265 & 0.002 & 0.428 \\
\hline ADG-DRT & 1.71 & 0.55 & 0.80 & 0.70 & 0.94 \\
\hline ADG-WRT & 2.03 & 0.75 & 1.00 & 0.27 & 1.01 \\
\hline \multicolumn{2}{|c|}{ Difference between time points } & $(2)-(1)$ & $(3)-(2)$ & $(5)-(4)$ & \\
\hline \multicolumn{2}{|l|}{ Mean } & $0.0001^{2}$ & 0.093 & 0.006 & \\
\hline \multicolumn{2}{|l|}{ Treatment } & $0.526^{3}$ & 0.991 & 0.030 & \\
\hline
\end{tabular}

p-value to compare DRT and WRT within a weighing time

$2 \mathrm{p}$-value to compare the effect of consecutive weighing times on ADG across time

$\mathrm{P}_{\mathrm{p}}$-value to compare the magnitude of the difference between DRT and WRT at consecutive weighing times, i.e. the treatment $\mathrm{x}$ time interaction

ferent at any time in the 3 years between the 2 treatments, except on 21 August, 1996. Although the clover content progressively dropped from 1994 to 1996 the authors observed that in 1997 under similar management the clover content of the field had once again increased to original levels.

\section{Discussion}

The results of this study indicated that the effect on weight gain of daily or weekly residence times varies seasonally. During 1995 and 1996, animals moved weekly tended to have higher average daily gain (ADG) than animals moved daily and these differences were significant early in each season. In June, forages in Nova Scotia are typically at their peak growth rate and the larger area, associated with a longer residence time, may provide more opportunities for cattle to select forage. Near the end of both grazing seasons the trend observed with cattle ADG

Table 4. Forage mass Dry Matter $\left(\mathrm{kg} \mathrm{ha}^{-1}\right)$ and clover content $(\%)$ prior to grazing by cattle in paddocks of animals with a daily residence time (DRT) and a weekly residence time (WRT).

\begin{tabular}{|c|c|c|c|c|c|}
\hline \multirow[b]{2}{*}{ Year } & \multirow[b]{2}{*}{ Date } & \multicolumn{2}{|c|}{ Available Dry Matter } & \multicolumn{2}{|c|}{ Clover Content } \\
\hline & & DRT & WRT & DRT & WRT \\
\hline & & $-\cdots$ & $-\ldots-$ & $-\cdots$ & $-\cdots$ \\
\hline \multirow[t]{7}{*}{1995} & 24 May & 126 & 116 & 13.0 & 12.8 \\
\hline & 29 May & 1803 & 1974 & 11.5 & 13.1 \\
\hline & 13 June & 2080 & 1974 & 4.7 & 6.7 \\
\hline & 20 June & 2071 & 1819 & 4.8 & 2.9 \\
\hline & 4 July & 1933 & 938 & 23.0 & 12.7 \\
\hline & 7 Aug. & 1631 & 1903 & 25.8 & 30.9 \\
\hline & 20 Aug. & 617 & 316 & 31.3 & 14.1 \\
\hline
\end{tabular}

1996

$\begin{array}{rrrrr}\text { 29 May } & 694 & 1012 & 4.6 & 15.0 \\ \text { 12 June } & 1465 & 1402 & 8.8 & 11.2 \\ \text { 26 June } & 2521 & 2255 & 4.5 & 2.3 \\ \text { 10 July } & 1330^{*} & 2691 & 23.0 & 14.2 \\ \text { 7 Aug. } & 815 & 860 & 9.8 & 15.4 \\ \text { 21 Aug. } & 1540^{*} & 1042 & 27.2^{*} & 11.3\end{array}$

Due to the timing of data collection the values obtained in 1995 cannot be compared statistically. The date given was when DRT paddocks were sampled. WRT paddocks may have been sampled 2 or 3 days before or after. *Means significantly different at the $5 \%$ level of significance. decreased. Rate of gain with weekly residence time may have declined near the end of the season because of their higher energy requirement coinciding with a requirement for more energy to obtain the forage. Near the end of the season the forage was shorter and larger paddocks were necessary to provide enough biomass which caused the animals to walk further and take more bites to obtain enough dry matter to support their rate of gain. Chacon et al. (1978) found that animals grazing a shorter sward took smaller bites and may not have been able to obtain enough dry matter regardless of the forage quality.

In both years the clover content in daily residence time paddocks tended to be higher late in the season suggesting a higher protein content. In several studies, neither continuous nor rotational stocking, nor stocking density has been found to affect pasture sward quality (Popp et al. 1997, Walker et al. 1989). Morrow et al. (1991) reported a decrease in forage quality in some pasture mixes (bromegrass and alfalfa) after the animals had been in a paddock for 3 days. Early in the grazing season forage quality may have been high and unaffected by grazing treatment. Near the end of the grazing season, when water is limiting and forage regrowth slows, short grazing periods within a paddock may maintain a higher forage quality and higher ADG.

Despite the high gains obtained on pasture, carcasses of animals raised solely on grass tend to be graded lower than animals finished in a feedlot (Bowling et al. 1977). Two major causes of the lower grading are yellow fat and lack of sufficient marbling. The amount of yellow fat on a carcass is partially due to fatness of animals, genetics, gender, and age (Walker et al. 1990). Consequently, many farmers finish their cattle on grain to increase the fat content of the carcass and reduce the incidence of yellow fat to avoid discounts on the price paid by packers (Muir et al. 1992). In this study without grain finishing, yellow fat was not 
apparent on carcasses, presumably because Herefords mature sooner than some larger breeds and the forage was of sufficient quantity and quality to finish the cattle before aging contributed to yellow fat.

\section{Conclusions}

Animals moved to a new paddock weekly (longer residence time) had higher average daily gain (ADG) than those moved daily (shorter residence time) in the early grazing season when forage was plentiful. At the end of each season when forage growth rate was low, cattle with a daily residence time had higher ADG. The results of this study indicate that animal performance could be maximized by long rotation cycles during periods of rapid forage growth and short rotation cycles during periods of slow forage growth. Pasture productivity remained constant in 1995 and 1996, while clover content of pasture declined throughout the experiment. In 1995 and 1996, all cattle (64 steers and heifers) were slaughtered directly from pasture without incidence of yellow fat on the carcasses.

\section{Literature Cited}

Bertelsen, B.S., D.B. Faulkner, D.D. Buskirk and J.W. Castree. 1993. Beef cattle performance and forage characteristics of continuous 6-paddock, and 11-paddock grazing systems. J. Anim. Sci. 71:1381-1389.

Bowling, R.A., G.C. Smith, Z.L. Carpenter, T.R. Dutson, and W.M. Oliver. 1977. Comparison of forage-finished beef and grain-finished beef carcasses. J. Anim. Sci. 45:209-215.

Chacon, E.A., T.H. Stobbs, and M.B. Dale. 1978. Influence of sward charcteristics on grazing behavior and growth of Hereford steers grazing tropical grass pastures. Aust. J. Agr. Res. 29:89-102.

Hart, R.H., J. Bissio, M.J. Samuel, and J.W. Waggoner JR. 1993. Grazing systems, pasture size, and cattle grazing behavior, distribution and gains. J. Range Manage. 46:81-87.

Heitschmidt, R.K., S.L. Dowhower, and J.W. Walker. 1987. Some effects of a rotational grazing treatment on quantity and quality of available forage and amount of ground litter. J. Range Manage. 40:318-321.

Montgomery, D.C. 1997. Design and analysis of experiments, 4th edition. Wiley, New York.
Morrow, R.E., V.G. Schulze-Tate, J.R Gerrish, and C.R. Roberts. 1991. Implications of daily quality changes in rotationally grazed pastures for beef cattle. Proc. of Forage and Grassl. Conf. of Columbia. 145-149.

Muir, P.D., G.J. Cruickshank, N.B. Smith, K.S. MacLean, and G.J. Wallace. 1992. A comparison of grain and pasture finishing of heavyweight cattle. Proc. of the New Zealand Soc. of Anim. Production. CAB Abstracts. 52:93-95.

Popp, J.D., W.P. McCaughey, and R.D.H. Cohen. 1997. Effect of grazing system, stocking rate and season of use on diet quality and herbage availability of alfalfa-grass pastures. Can. J. Anim. Sci. 77:111-113.

SAS Institute Inc. 1990. SAS/STAT user's guide, version 6, 4th edition, Vol.2, Cary, N.C: SAS Institute Inc.

Walker, J.W., E.A. DeMoraes, R.K. Heitschmidt, M.M. Kothmann, and S.L. Dowhower. 1989. Quality and botanical composition of cattle diets under rotational and continuous grazing treatments. J. Range Manage. 42(3):239-242.

Walker, P.J., R.D. Warner, and C.G. Winfield. 1990. Sources of variation in subcutaneous fat colour of beef carcasses. Proc. of the Aust. Soc. of Anim. Prod. CAB Abstracts. 18:416-419. 